\title{
Physiological performance of white oat seeds coated with zinc
}

\section{Qualidade fisiológica de sementes de aveia branca recobertas com zinco}

\author{
Felipe SCHWERZ1'; Braulio Otomar CARON²; Stela Maris KULCZYNSNKI³; Elvis Felipe ELLI ${ }^{4}$; \\ Douglas Machado de OLIVEIRA ${ }^{5}$; Vinícius SAZARESKI ${ }^{5}$
}

\begin{abstract}
${ }^{1}$ Autor para correspondência; Acadêmico do curso de Agronomia; Centro de Educação Superior Norte - RS, Universidade Federal de Santa Maria; Departamento de Ciências Agronômicas e Ambientais; Linha Sete de Setembro, s/n, - BR 386 KM 40, CEP 98400-000, Frederico Westphalen/RS. E-mail.: felipe_schwerz@hotmail.com

${ }^{2}$ Engenheiro Agrônomo, Dr., Professor do Centro de Educação Superior Norte - RS, Universidade Federal de Santa Maria. Email.: otomarcaron@yahoo.com.br

${ }^{3}$ Engenheira Agrônoma, Dra., Professora do Centro de Educação Superior Norte - RS, Universidade Federal de Santa Maria. E-mail.: stelamk@terra.com.br

${ }^{4}$ Mestrando do Programa de Pós Graduação em Agronomia - Agricultura e Ambiente, do Centro de Educação Superior Norte - RS, Universidade Federal de Santa Maria. E-mail.: elvisfelipeelli@yahoo.com

${ }^{5}$ Acadêmicos do curso de Agronomia, Centro de Educação Superior Norte - RS, Universidade Federal de Santa Maria. Email.: douglas.mdo@hotmail.com; viniszareski@hotmail.com
\end{abstract}

\section{Recebido em: 11-02-2015; Aceito em: 26-05-2015}

\begin{abstract}
The physiological seed quality is a major factor affecting the culture performance and is related to genetic attributes, physical, physiological and seed sanitary. Thus, the objective was to evaluate the physiological potential of seeds of three white oat cultivars treated with zinc. The experiment was conducted in the seed analysis laboratory of the Federal University of Santa Maria campus Frederico Westphalen-RS in September 2014. Was used the completely randomized design, with the treatments distributed in a factorial $3 \times 5$, being three white oat cultivars (Taura, Guria and Fapa 43) and five doses of the product Teprosyn ${ }^{\mathrm{TM}} \mathrm{Zn}\left(0,5,10,15\right.$ and $20 \mathrm{~mL} \mathrm{~kg}^{-1}$ seed), with four repetitions of 100 seeds. The physiological quality of treated seeds was evaluated by the germination test, first count, length of radicle, cold test and accelerated aging test. The germination of the seeds of the cultivars Guria, Taura and Fapa 43 is not affected for doses of zinc up to $20 \mathrm{mg} \mathrm{kg}^{-1}$ of seed. The dose of $10 \mathrm{~mL} \mathrm{~kg}^{-1}$ seed provides the best results for culture, with a significant increase on its vigor, differently among cultivars, through the increment in root length of the cultivars Guria and Fapa 43 and accelerated aging for the cultivars Taura and Fapa 43. The cultivar Taura showed the highest physiological potential, since has obtained the highest germination values, and greater vigor in the cold tests and radicle length.
\end{abstract}

Additional keywords: Avena sativa L.; micronutrient; seed treatment.

\section{Resumo}

A qualidade fisiológica das sementes é um dos principais fatores que afetam o desempenho da cultura e está relacionada aos atributos genéticos, físicos, fisiológicos e sanitários das sementes. Assim, objetivou-se avaliar o potencial fisiológico de sementes de três cultivares de aveia-branca tratadas com zinco. O experimento foi conduzido no laboratório de análise de sementes, da Universidade Federal de Santa Maria, Câmpus de Frederico Westphalen - RS, em setembro de 2014. Utilizou-se o delineamento inteiramente casualizado, com os tratamentos distribuídos em esquema fatorial $3 \times 5$, sendo três cultivares de aveia-branca (Taura, Guria e Fapa 43) e cinco doses do produto Teprosyn ${ }^{\mathrm{TM}} \mathrm{Zn}\left(0 ; 5 ; 10 ; 15\right.$ e $20 \mathrm{~mL} \mathrm{~kg}^{-1}$ de semente), com quatro repetições de 100 sementes. A qualidade fisiológica das sementes tratadas foi avaliada pelos testes de germinação, primeira contagem, comprimento de radícula, teste de frio e teste de envelhecimento acelerado. A germinação das sementes das cultivares Guria, Taura e Fapa 43 não é afetada por doses de zinco até $20 \mathrm{mg} \mathrm{kg}^{-1}$ de semente. A dose de $10 \mathrm{~mL} \mathrm{~kg}^{-1}$ de sementes proporciona os melhores resultados para a cultura, com aumento significativo em seu vigor, de forma diferente entre as cultivares, através do incremento no comprimento radicular das cultivares Guria e Fapa 43, e no envelhecimento acelerado para as cultivares Taura e Fapa 43. A cultivar Taura apresentou o maior potencial fisiológico, uma vez que obteve os maiores valores de germinação, bem como maior vigor nos testes de frio e no comprimento radicular.

Palavras-chave adicionais: Avena sativa L.; micronutriente; tratamento de sementes. 


\section{Introduction}

The increase in the white oat (Avena sativa L.) cultivation in recent years comes from the benefits offered by the culture in the production system, giving producers an attractive alternative for cultivation in winter (Fontaneli, 2012). Due to the importance of the culture both for animal feed and for grain production, it is necessary to worry about the quality of seeds used by farmers in order to obtain higher yields.

The physiological seed quality is a major factor affecting culture performance and is related to genetic, physical, physiological and sanitary attributes (Marcos Filho, 2005). Among these attributes, the determination of the physiological potential is critical for quality control programs, as it allows the quantification of seed potential in different environmental conditions through tests such as of germination and vigor. The use of high quality seeds is the starting point for emergency and greater uniformity of plant stand, thus ensuring the yield potential of the crop.

Hence, for the use of white oat in agricultural production and crop-livestock integration systems to be sustainable and economically viable, is of fundamental importance to improve and identify responses thereof to different external stimuli during the production cycle. The production and physiological performance of seeds are subject to the availability of nutrients found in the production system, which can affect the formation of the embryo and storage organs, as well as the chemical composition, metabolism and vigor (Scheeren, 2002). Among these nutrients, zinc (Zn) has a great importance during the stages of formation, development and maturation of seeds (Sá, 1994). According to Teixeira et al. (2005), the nutritional requirement of crops becomes more significant at the beginning of the reproductive stage, being more critical in the time of seed formation. However, according to Ribeiro \& Santos (1996), most Brazilian soils have inadequate levels of $\mathrm{Zn}$, ie, below the recommended level for agricultural crops.

The low concentration of $\mathrm{Zn}$ in the seeds may result in seedlings with less vigor, because this nutrient is considered an element that accelerates the radicle growth of some species such as rice (Ohse et al., 2000) and wheat (Prado et al., 2007), possibly having the same effect for white oat.

Application of micronutrients by seed coating is an effective option to provide with precision and uniformity the small doses indicated for the culture. Seed treatment keeps these elements in direct contact with the issuance of the first roots, thus supplying the initial needs of the plant, taking into account that in the early stages of development the culture has undeveloped root system, and this affects the absorption of micronutrients in the soil (Bonnecarrère et al., 2004).

However, it is possible that the seed treatment with $\mathrm{Zn}$ enables increases in seedling germination and vigor, considering that the enzymatic activity and the proper functioning of cell membranes are essential for germination, as they interfere with the synthesis and degradation of compounds during the mobilization of the reserves, as well as with the cell expansion, division and growth, which occur during germination (Nonogaki et al., 2010).

Some studies have already demonstrated the influence of $\mathrm{Zn}$ application on physiological performance of seeds such as rice (Funguetto et al., 2010), sorghum (Yagi et al., 2006; Santos et al., 2008), wheat (Ohse et al., 2012), among others.

The knowledge of the performance of $\mathrm{Zn}$ doses on physiological quality of white oat seeds, especially with regard to physiological potential, is important in light of the insufficient information regarding the effect of this micronutrient for culture. Given the above, it was aimed to evaluate the physiological potential of seeds of three white oat cultivars treated with zinc.

\section{Material and methods}

The experiment was carried in the seed analysis laboratory of the Federal University of Santa Maria, Campus of Frederico Westphalen - RS, in September 2014. The seeds were purchased from the wheat culture cooperative Sarandi Ltda. (Cotrisal); they were viable, with germination above $80 \%$ according to the minimum standards for marketing of this culture seeds (BRASIL, 2005), which gives the study a good representation of the data.

The experimental design was completely randomized, following a factorial $3 \times 5$, being three white oat cultivars (Taura, Guria and Fapa 43) and five doses of the product Teprosyn ${ }^{\mathrm{TM}} \mathrm{Zn}\left(0,5,10,15\right.$ and $20 \mathrm{~mL} \mathrm{~kg}^{-1}$ seed), with four replications of 100 seeds. The zinc-based product has the following characteristics: $1.67 \mathrm{~kg} \mathrm{~L}^{-1}$ density, having in its constitution $17 \mathrm{~g} \mathrm{~L}^{-1}(1 \%)$ of nitrogen and $600 \mathrm{~g} \mathrm{~L}^{-1}(36 \%)$ of $\mathrm{Zn}$.

The initial water contents of the white oat seeds were standardized to values close to $13 \%$, being these features essential for standardization of evaluations and achievement of consistent results.

Seed treatment was performed in polyethylene bags, following the procedure described by Nunes (2005), wherein the source of $\mathrm{Zn}$ was placed in bags in their respective doses, along with water. Then it was added $100 \mathrm{~g}$ of seed and shaken for three minutes, performing, then, the drying at room temperature for 24 hours.

by the following tests:

Germination $(G)$ - conducted with four replications of 100 seeds for each treatment. The seeds were placed on "germitest" paper rolls, moistened with distilled water at a ratio of 2.5 times the dry weight of the paper, and maintained in a growth chamber equipped with four fluorescent tubes $(20 \mathrm{~W})$ in scheme of 12 hours with light (daytime) and 12 hours without light (nighttime), at a constant temperature of $20^{\circ} \mathrm{C}$. Being counts performed at 10 days after the start of the 
test, according to criteria established by the Rules for Seed Analysis (RSA) (BRASIL, 2009), and the results expressed as a percentage.

First germination count (1st Count) - held together with the germination test, computing the average percentage of normal seedlings on the fifth day after the test facility, according to RSA (BRASIL, 2009).

Radicle length $(R L)$ - for the determination of this variable, four replicates of fifteen seeds were used, being seeded on "germitest" paper rolls moistened with distilled water at a ratio of 2.5 times the dry weight of the paper, and kept in germinator set at $20^{\circ} \mathrm{C}$. The rolls with seeds remained for 10 days in germination chamber. To measure the data, a ruler was used, being the results expressed in centimeters $(\mathrm{cm})$.

Cold test (CT) - performed with four repetitions of 100 seeds, distributed in "germitest" rolls moistened with distilled water equivalent to 2.5 times the dry weight of the paper. After seeding, the rolls were placed in plastic bags and sealed with elastic rubber being kept in a chamber set at $10^{\circ} \mathrm{C}$ for seven days. Then the rolls were transferred to a growth chamber at a constant temperature of $20^{\circ} \mathrm{C}$, where they remained for five days. The evaluations were performed according to RSA (BRASIL, 2009).

Accelerated aging (AA) - using the method proposed by Elliot (1991), wherein 400 seeds were arranged in a single layer and distributed over an aluminum screen, fixed inside a plastic box with dimensions of $11 \mathrm{~cm} \times 11 \mathrm{~cm} \times 3 \mathrm{~cm}$. Within this box, it was added $40 \mathrm{~mL}$ of distilled water and, then, the boxes were taken to aging chamber at a constant temperature of $42{ }^{\circ} \mathrm{C}$, for a period of 72 hours (Fidelis et al., 2013). After this period, the seeds were put to germinate, according to the methodology described for the germination test, following the criteria established by RSA (BRASIL, 2009).

Data were subjected to statistical analysis by means of the computer program Statistical Analysis System Learning Edition 8.0 (SAS, 2003). The parameters that showed statistically significant differences at the level of $5 \%$ error probability were compared using the Tukey test for cultivar factor and regression to dose of Teprosyn ${ }^{\mathrm{TM}} \mathrm{Zn}$.

\section{Results and discussions}

According to the analysis of variance (Table 1 ), it is possible to observe significant effects in the interaction (Cultivar $x$ Dose) for the variables germination, first count, radicle length, cold test and accelerated aging, by $F$ test at probability $(p<0.05)$.

There was no significant difference regarding the increase in doses used for germination variable (Table 2). These results are in agreement with those found by Ohse et al. (2012), by concluding that the zinc doses applied via seed treatment did not affect the germination of seeds of wheat cultivars. Also Funguetto et al. (2010), working with rice seeds coated with zinc sulfate, found no differences in germination. In contrast, Yagi et al., (2006) reported a reduction in the percentage of the germination of sorghum seeds treated with zinc.

Differences were observed among cultivars, being the highest average values of germination, in descending order, found to Taura (93.5\%), Fapa 43 $(91.2 \%)$ and Guria (83.2\%). There is $11 \%$ reduction in germination between Taura and Guria cultivars, such results may be related to physiological quality and genetic factor of each evaluated cultivar. However, it is observed that regardless of $\mathrm{Zn}$ doses applied, germination remained above the minimum value of $80 \%$.

The different response between cultivars in germination may be related to differences in sensitivity of each cultivar to the application of $\mathrm{Zn}$, as this micronutrient provides different effects between species, and even among cultivars within the same species. Confirming the hypothesis of Borkert et al. (1998), in which the amplitude of the variation of the beneficial and critical content (toxic effect) of zinc doses for cultures is related to differences in tolerance between cultivars of the same species.

Table 1 - Analysis of variance for the germination test $(G)$, first count ( $1^{\text {st }}$ Count), radicle length $(R L)$, cold test $(C T)$ and accelerated aging test $(A A)$ in white oat cultivars submitted to different doses of the product Teprosyn $^{\text {TM }}$ Zn. UFSM/CESNORS Campus of Frederico Westphalen - RS, 2014.

\begin{tabular}{lcccccc}
\hline \multirow{2}{*}{ Study factor } & \multirow{2}{*}{ DF } & \multicolumn{5}{c}{ Mean square } \\
\cline { 3 - 7 } & & $\mathrm{G}$ & $1^{\text {st }}$ Count & $\mathrm{RL}$ & $\mathrm{CT}$ & $\mathrm{AA}$ \\
\hline Cultivar & 2 & $586.12^{*}$ & $413.84^{*}$ & $41.13^{*}$ & $588.86^{*}$ & $3.60^{\text {ns }}$ \\
Dose & 4 & $6.85^{\text {ns }}$ & $28.24^{\text {ns }}$ & $1.72^{\text {ns }}$ & $24.43^{*}$ & $833.90^{*}$ \\
Cultivar x Dose & 8 & $17.2^{*}$ & $37.56^{*}$ & $8.62^{*}$ & $30.54^{*}$ & $255.34^{*}$ \\
$\mathrm{R}^{2}$ & - & 0.82 & 0.74 & 0.80 & 0.85 & 0.84 \\
CV $(\%)$ & - & 3.00 & 4.00 & 9.15 & 2.88 & 7.71 \\
\hline
\end{tabular}

* Significant at $5 \%$ of error probability; ${ }^{\text {ns }}$ non-significant at $5 \%$ of error probability; $\mathrm{R}^{2}$ : coefficient of determination; CV: coefficient of variation. 
Table 2 - Means of the germination test $(G)$, first count (1 $1^{\text {st }}$ Count), radicle lenght (RL), cold test $(C T)$ and accelerated aging test (AA) of white oat cultivars under different doses of the product Teprosyn ${ }^{\mathrm{TM}} \mathrm{Zn}$. UFSM/CESNORS Campus of Frederico Westphalen - RS, 2014.

\begin{tabular}{|c|c|c|c|c|c|c|}
\hline \multirow{2}{*}{ Variable } & \multirow{2}{*}{ Cultivar } & \multicolumn{5}{|c|}{ Dose } \\
\hline & & 0 & 5 & 10 & 15 & 20 \\
\hline \multirow{3}{*}{ G } & Fapa 43 & $89.25 \mathrm{a}$ & $94.25 a$ & $90.50 \mathrm{~b}$ & $92.25 \mathrm{a}$ & $90.00 \mathrm{~b}$ \\
\hline & Guria & $84.75 \mathrm{~b}$ & $82.25 b$ & $84.50 \mathrm{c}$ & $84.75 \mathrm{~b}$ & 79.75 c \\
\hline & Taura & $92.75 \mathrm{a}$ & $92.50 \mathrm{a}$ & $94.66 \mathrm{a}$ & $93.00 \mathrm{a}$ & $95.00 \mathrm{a}$ \\
\hline \multirow{3}{*}{$1^{\text {st }}$ Count. } & Fapa 43 & $86.00 \mathrm{a}$ & $90.75 a$ & $85.00 \mathrm{~b}$ & $88.50 \mathrm{a}$ & $82.33 \mathrm{~b}$ \\
\hline & Guria & $79.00 \mathrm{~b}$ & $77.33 \mathrm{~b}$ & 81.75 b & $81.50 \mathrm{~b}$ & $74.75 \mathrm{c}$ \\
\hline & Taura & $83.67 \mathrm{ab}$ & $88.50 \mathrm{a}$ & $90.25 \mathrm{a}$ & $84.25 a b$ & 89.00 a \\
\hline \multirow{3}{*}{ CR } & Fapa 43 & $7.67 \mathrm{c}$ & $9.99 b$ & $10.92 \mathrm{~b}$ & $9.35 \mathrm{~b}$ & $10.82 \mathrm{ab}$ \\
\hline & Guria & $11.39 \mathrm{~b}$ & $12.65 \mathrm{a}$ & $13.87 \mathrm{a}$ & $12.12 \mathrm{a}$ & $10.40 \mathrm{~b}$ \\
\hline & Taura & $13.62 \mathrm{a}$ & $12.94 \mathrm{a}$ & $10.03 \mathrm{~b}$ & $13.53 \mathrm{a}$ & $12.17 \mathrm{a}$ \\
\hline \multirow{3}{*}{ TF } & Fapa 43 & $93.25 \mathrm{a}$ & $93.25 \mathrm{a}$ & $91.75 \mathrm{a}$ & $90.25 \mathrm{a}$ & $92.25 \mathrm{a}$ \\
\hline & Guria & $86.50 \mathrm{~b}$ & $83.33 b$ & 86.67 b & $82.75 \mathrm{~b}$ & $75.33 \mathrm{~b}$ \\
\hline & Taura & $94.25 \mathrm{a}$ & $93.00 \mathrm{a}$ & $93.00 \mathrm{a}$ & $92.25 \mathrm{a}$ & $95.75 \mathrm{a}$ \\
\hline \multirow{3}{*}{ EA } & Fapa 43 & $75.00 \mathrm{ab}$ & $73.00 \mathrm{a}$ & $74.00 \mathrm{a}$ & $69.75 \mathrm{~b}$ & $54.25 \mathrm{~b}$ \\
\hline & Guria & $68.00 \mathrm{~b}$ & $69.25 \mathrm{a}$ & $72.33 \mathrm{a}$ & $71.50 \mathrm{~b}$ & $67.33 \mathrm{a}$ \\
\hline & Taura & $78.75 \mathrm{a}$ & $69.75 \mathrm{a}$ & $78.25 \mathrm{a}$ & $80.00 \mathrm{a}$ & $36.33 \mathrm{c}$ \\
\hline
\end{tabular}

Means followed by the same letter in the column do not differ at $5 \%$ error probability according to Tukey test.

On the first count, certain resemblance to the result obtained in the germination variable is found. The Taura and Fapa 43 cultivars had the highest germination results in most of the tested doses (Table 2). Taura cultivar showed the highest values of radicle length, only surpassed at a dose of $10 \mathrm{~mL} \mathrm{~kg}^{-1}$ seed for Guria cultivar (Table 2). The increase in radicle length influenced by the application of $\mathrm{Zn}$ is probably due to the fact that this element plays important roles in plant metabolism, performing the synthesis of the amino acid tryptophan, precursor of phytohormones like auxin, responsible, mainly, for root cell elongation and differentiation (Taiz \& Zeiger, 2009; Overvoorde et al., 2010).

The largest cold test values were checked for Taura and Fapa 43 cultivars, in contrast, Guria cultivar demonstrated the lowest results in all doses studied (Table 2). Even with values lower than those obtained by other cultivars, it can be inferred that the batch of cultivar seeds showed high strength when subjected to an unfavorable condition, in case, the cold. These results go against those obtained by Tavares et al. (2015), who, working with doses of zinc in the physiological potential of barley seeds, found that the different zinc doses did not affect the seed vigor through the cold test.

In the accelerated aging test, it was found that the cultivars showed no significant difference in the values, only in doses of 5 and $10 \mathrm{ml} \mathrm{kg}^{-1}$ seed, and the lowest germination rates were obtained in the treatments with application of $20 \mathrm{~mL} \mathrm{~kg}^{-1}$ seed, so that
Taura cultivar had the lowest values (Table 2).

The observed reduction is due to the toxic effect provided by the excess of zinc in plant cells, because when found in large quantities, it can give damage to the cell structure, mainly affecting the integrity of the cell membrane (Malavolta, 2006). Thus, the damage, added to high temperature imposed on seeds in the accelerated aging test, favored reducing the physiological potential of seeds.

Seed exposure to high heat and humidity causes serious changes in seed metabolism, triggering the disruption and loss of integrity of the cell membrane system (Dias \& Marcos Filho, 1995). Paiva et al. (2008), performing the accelerated aging test in fodder seeds at 41 and $45^{\circ} \mathrm{C}$, with 48,72 and $96 \mathrm{~h}$ periods of exposure to the test, observed that when the $45^{\circ} \mathrm{C}$ temperature was used, lower germination percentages occured.

A significant response to the first count variable (Figure 1) in relation to the increase of $\mathrm{Zn}$ doses was observed, noting quadratic response for Taura cultivar, being the highest value reached at a dose of $10 \mathrm{ml} \mathrm{kg}^{-1}$ seed. The Guria and Fapa 43 cultivars showed no significant difference, with linear fit of the equation. Individual seed vigor can be manifested in various ways for the cultivars, as well as the continuity of the test on the fifth day after the germination (when the first counting test is done) promotes the expression of the maximum germination potential, even in those seeds that have less vigor. 

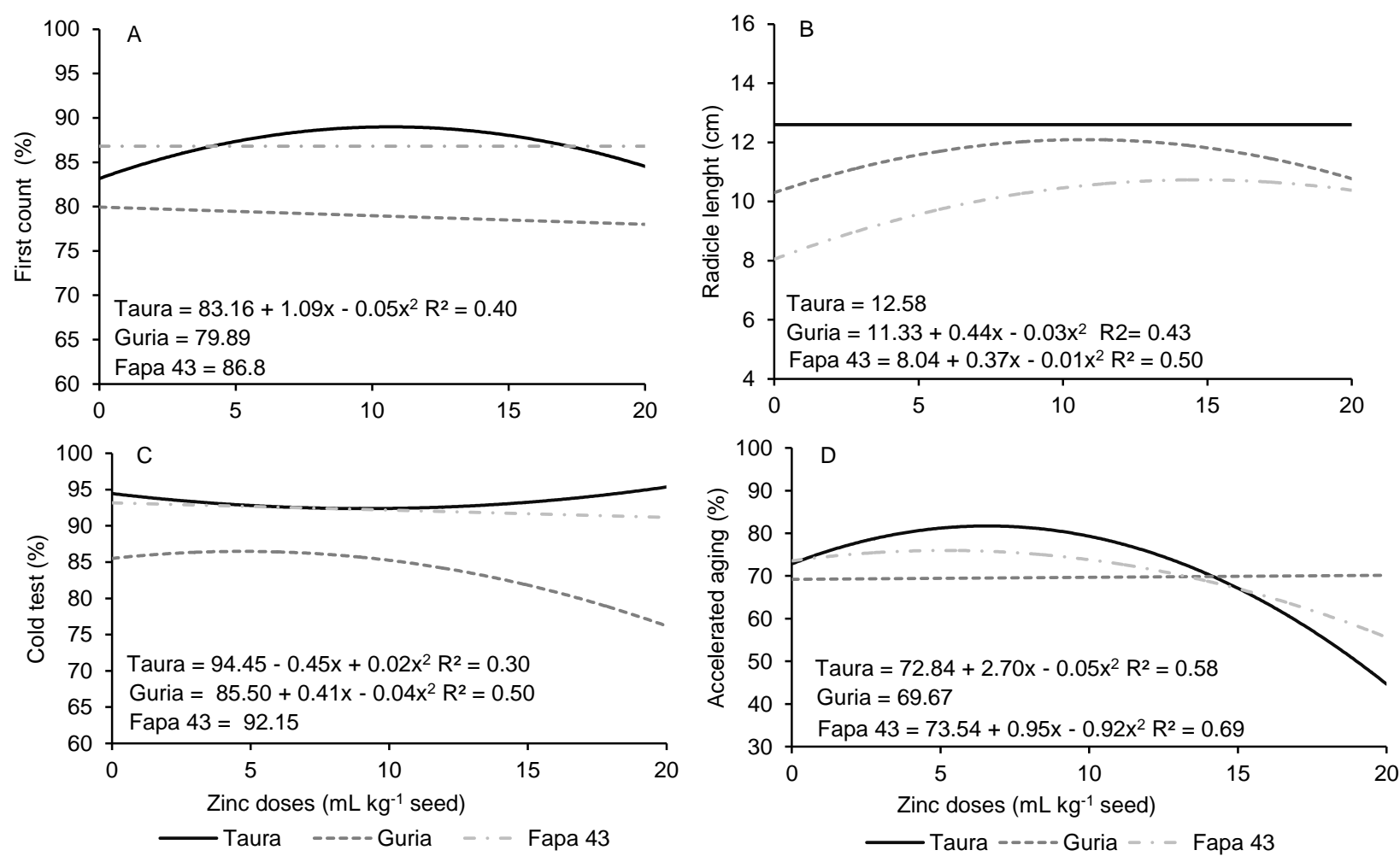

Figure 1 - Regression equations of the tests first count, radicle lenght (RL), cold test (CT), and accelerated aging test (AA) of white oat cultivars under different doses of the product Teprosyn ${ }^{\text {TM }}$ Zn. UFSM/CESNORS Campus of Frederico Westphalen - RS, 2014.

Evaluating different vigor tests for white oat seeds, Tunes et al. (2008) found values of first count of over $70 \%$. Although the first count of the germination test is considered indicative of stength, it is observed that in certain situations it does not allow the identification of small differences for this trait, resulting in values close to those obtained in the final germination test.

Analyzing the radicle length (Figure 1), it appears that the cultivars have different responses to zinc doses, demonstrating sensitivity to the effects of this micronutrient; Taura cultivar showed no significant response in relation to the increase of $\mathrm{Zn}$ doses. For Guria and Fapa 43 cultivars, there were quadratic equation adjustments, with the point of maximum radicle length achieved at a dose of $10 \mathrm{ml} \mathrm{kg}^{-1}$ seed. Likewise, Ohse et al. (2000), comparing different treatments of rice seeds with micronutrients zinc, boron and copper, which had the highest values for radicle length with zinc at a dose $0.67 \mathrm{~kg}^{-1} \mathrm{~kg}$ seed.

In relation to Guria cultivar, there was $18 \%$ increase in radicle length, in which at the dose of 10 $\mathrm{mL} \mathrm{kg}{ }^{-1}$ seed, length was $13.87 \mathrm{~cm}$ and the witness had lower average of $11.38 \mathrm{~cm}$. To Fapa 43 cultivar, there was even greater increase in radicle length, around $30 \%$, yielding $10.92 \mathrm{~cm}$ at the dose of $15 \mathrm{ml} \mathrm{kg}$ ${ }^{1}$ seed, and the witness with an average of $7.67 \mathrm{~cm}$. Similar responses were obtained by Funguetto et al. (2010), working with rice seeds coated with zinc sulfate, who found $26 \%$ increase in radicle length, compared to zero dose, increase of $4 \mathrm{~cm}$ root.
The beneficial effect of seed treatment with $\mathrm{Zn}$ on the radicle length can be associated with the fact that the element is considered an enzymatic activator, thus conducting the synthesis of proteins by the embryonic axis, which will result in the seedling. This process, being enhanced in the seed that is in germinating phase, causes the embryonic axis to create a more vigorous seedling.

For the cold test, there was a quadratic response to the Guria and Taura cultivars (Figure 1), with higher values obtained at doses of 10 and 20, respectively. It is interesting to note that the cultivars of Taura and Fapa 43, when subjected to low temperatures in the initial stage of germination, did not suffer reduction in germination potential, even without treatment with zinc, which may be associated with these genotypes tolerance to low temperatures conditions. In contrast, Guria cultivar decreased by $13 \%$ for this feature when subjected to the application of the highest dose. Thus, the application of doses above $15 \mathrm{~mL} \mathrm{~kg}^{-1}$ seed, added to cold conditions, reduce the germination rate for this cultivar.

By analyzing the accelerated aging test (Figure 1), it can be seen that the Guria cultivar presented no significant response with increasing doses of Zn. However, Taura and Fapa 43 cultivars showed a quadratic response, with the highest values for this characteristic at a dose of $10 \mathrm{~mL} \mathrm{~kg}^{-1}$ seed. The two cultivars behaved similarly, whereas with the increase in zinc dose, there was reduction in germination, close to 22 and $16 \%$ for Taura and Fapa 43 cultivars, 
respectively. This reduction is associated with the toxic effects of zinc, being the same required in small amounts, presenting narrow strip between the beneficial effect and the toxicity (Malavolta, 2006).

Possibly, this result is related to the toxic effect provided by higher doses of zinc, resulting in the reduction of the physiological performance of seed, as this element when in larger quantities usually induces oxidative damage, giving birth to the peroxidation of lipids and degradation of other compounds in plant (Malavolta, 2006). Similar results were described by Gonçalves Junior et al. (2005), who found that the application of $\mathrm{Zn}$ in maize seed damaged the emergence of plants, with the most dramatic effects at the dose of $5.0 \mathrm{~g} \mathrm{~kg}^{-1}$ seed.

\section{Conclusions}

The seeds germination of Guria, Taura and Fapa 43 cultivars is not affected by zinc up to $20 \mathrm{mg} \mathrm{kg}^{-1}$ seed.

The dose of $10 \mathrm{~mL} \mathrm{~kg}^{-1}$ seed provides the best results for culture, with a significant increase in its vigor, differently among cultivars, through the increase in radicle length of Guria and Fapa 43 cultivars and in accelerated aging for Taura and Fapa 43 cultivars.

Taura cultivar has the highest physiological performance, since it obtained the highest germination values, as well as greater vigor in tests of cold and radicle length.

\section{References}

Bonnecarrère RAG, Londero FAA, Santos O, Schmidt D, Pilau FG, Manfron PA, Neto DD (2004) Resposta de genótipos de arroz irrigado à aplicação de zinco. Revista Faculdade Zootecnia Veterinária e Agronomia 10(1):214-222.

Borkert CM, Cox FR, Tucker MR (1998) Zinc and copper toxicity in peanut, soybean, rice and corn in soil mixtures. Communication Soil Science Plant Analysis 29(1):2991-3005.

BRASIL (2009) Regras para análise de sementes. Brasília, DF:MAPA/SNDA/DNDV/CLAV, 398p.

BRASIL (2005) Padrões para produção e comercialização de sementes de aveia. Brasília, DF:MAPA. Disponível em: <http://www.agricultura.pr.gov.br/arquivos/ File/PDF/padroes_aveia.pdf> (Acesso em 6 de nov 2014).

Dias DCSF, Marcos Filho J (1995) Testes de vigor baseados na permeabilidade das membranas celulares: II. Lixiviação de potássio. Informativo Abrates 5(1):37-41.

Elliot B (1991) Construção do recipiente das sementes para uso do teste de envelhecimento precoce. Informativo Abrates 1(2):51-53.

Fidelis RR, Nascimento IC, Santos MM, Silva GF, Tonello IP, Oliveira TC (2013) Efeito da adubação fosfatada na qualidade fisiológica de sementes de arroz cultivadas em terras altas. Bioscience Journal 29(1):15-21.
Fontaneli RS (2012) Valor nutritivo das aveias para produção animal. In: Reunião Anual da Comissão Brasileira de Pesquisa de Aveia, Passo Fundo: EMBRAPA p.1-12.

Funguetto Cl, Pinto JF, Baudet L, Peske ST (2010) Desempenho de sementes de arroz irrigado recobertas com zinco. Revista Brasileira de Sementes 32(2):115-117.

Gonçalves Junior AC, Ribeiro OL, Santos AL, Sacon $E$, Mondardo $E$ (2005) Emergência de plântulas de milho em resposta ao tratamento de sementes com zinco. Revista Varia Scientia 5(10):145-153.

Malavolta E (2006) Manual de nutrição mineral de plantas. São Paulo: Editora Agronômica Ceres. 638 p.

Marcos Filho J (2005) Fisiologia de sementes de plantas cultivadas. Piracicaba: FEALQ. 495 p.

Nonogaki H, Bassel GWE, Bewley JD (200) Germination - Still a mystery. Plant Science 179(6):574-581.

Nunes JC (2005) Tratamento de semente qualidades e fatores que podem afetar a sua performance em laboratório. São Paulo: Syngenta Proteção de Cultivos. $16 \mathrm{p}$.

Ohse S, Marodim V, Santos OS, Lopes SJ, Manfron PA (2000) Germinação e vigor de sementes de arroz irrigado tratadas com zinco, boro e cobre. Revista Faculdade Zootecnia Veterinária e Agronomia 7(1):73-79.

Ohse S, Cubis JG, Rezende BLA, Cortez MG, Otto RF (2012) Vigor e viabilidade de sementes de trigo tratadas com zinco. Biotemas 25(1):49-58.

Overvoorde P, Fukaki HE, Beeckman T (2010) Auxin Control of Root Development. Cold Spring Harbor Perspectives in Biology 2(6):1-16.

Paiva AS, Rodrigues TJD, Cancian AJ, Lopes MM, Fernandes AC (2008) Qualidade física e fisiológica de sementes da leguminosa forrageira Macrotyloma acillare cv. Java. Revista Brasileira de Sementes 30(2):130-136.

Prado RM, Frade J, Ferreira E, Mouta ER, São João ACG, Costa RSS (2007) Crescimento inicial e estado nutricional do trigo submetido à aplicação de zinco via semente. Revista de la Ciencia del Suelo y Nutrición Vegetal 7(1):22-31.

Ribeiro ND, Santos OS (1996) Aproveitamento do zinco aplicado na semente na nutrição da planta. Ciência Rural 26(1):159-165.

Sá ME (1994) Importância da adubação na qualidade de semente. In: SÁ ME, BUZZETI S (Ed.). Importância da adubação na qualidade dos produtos agrícolas. São Paulo: Ícone, p.65-98. 
Santos HC, Viana JS, Gonçalves EP, Bruno RLA, Fraga VS (2008) Qualidade fisiológica de sementes de sorgo em resposta à adubação com cobre e zinco. Caatinga 21(1):64-70.

SAS - Sas Learning Edition (2003) Getting started with the SAS Learning Edition. Cary. 200p.

Scheeren B (2002) Vigor de sementes de soja e produtividade. UFPEL, (Tese de Doutorado em Ciência e Tecnologia de Sementes).

Tavares LC, Brunes AP, Araújo Rufino C, Fonseca DAR, Gadotti GI, Villela FA (2015) Tratamento de sementes de cevada com zinco: potencial fisiológico e produtividade de sementes. Semina: Ciências Agrárias 36(2):585-594.
Teixeira IR, Borém A, Araújo GDA, Andrade MD (2005) Teores de nutrientes e qualidade fisiológica de sementes de feijão em resposta à adubação foliar com manganês e zinco. Bragantia 64(1):83-88.

Taiz L, Zeiger E (2009) Fisiologia vegetal. 4. ed. Artmed, $820 \mathrm{p}$.

Tunes LM, Olivo F, Badinelli PG, Cantos A, Barros ACSA (2008) Testes de vigor em sementes de aveia branca. Revista da FZVA 15(2):94-106.

Yagi R, Simili FF, Araújo JC, Prado RM, Sanchez SV, Ribeiro CER, Barretto VCM (2006) Aplicação de zinco via sementes e seu efeito na germinação, nutrição e desenvolvimento inicial do sorgo. Pesquisa Agropecuária Brasileira 41(4):655-660. 